and the attitude of the courts. Its demise to the extent noted, however, is to be welcomed. The more recent Supreme Court approach tries to pay attention to underlying conceptions of state policy. ${ }^{36}$ This seems a more reasonable basis for rules of law than what might be called a "jurisprudence of conceptions." Yet, as indicated, this rule raises problems of its own. Conflicts and confusion may result. The increasing power of the states to travel independent paths of social policy may well be undesirable in a nation whose problems are nation-wide in scope and whose aim is interstate harmony.

The Constitution of the United States provides an adequate remedy. Section I of Article 4 declares: "Full Faith and Credit shall be given in each State to the public Acts, Records, and judicial Proceedings of every other State. And the Congress may by general Laws prescribe the Manner in which such Acts, Records and Proceedings shall be proved, and the Effect thereof." "37 Thus far Congress has only slightly used this power; yet it seems broad enough to empower Congress to work out principles sufficient to dispel the present uncertainties. ${ }^{38}$

\title{
THE RULE IN SHELLEY'S CASE-AN ARGUMENT FOR ITS ABROGATION
}

$T$ devised certain property to A for life with a remainder to A's surviving children. The devise further provided, that if A died leaving no children surviving her, then the "title to the real estate named in this item to vest in fee simple in the brothers \& sisters and their heirs, of her the said [A] who may survive her." A's brothers and three sons of her deceased sister quit-claimed all their interest in the premises to A. Some forty years later, A died leaving no children surviving her. Her three brothers and her sister had predeceased her. A sought to dispose of the property by will. Certain children, the heirs of the brothers and sister, contended that the word "heirs" in the devise over to the "brothers and sisters and their heirs" designated them as a class of purchasers. In answer to this contention, the court held that "the words 'their heirs' are words of limitation and not of purchase and the rule in Shelley's Case

\footnotetext{
${ }^{36}$ Even in the Hoopeston case the Court's analysis was simplified, however. Only the social policy of New York was considered. The problems of Illinois, if any, and their relation to the general problem of regulation were ignored.

${ }^{37}$ Italics added.

${ }^{38} \mathrm{Cook}$, The Powers of Congress under the Full Faith and Credit Clause, 28 Yale L. J. 42I (IgIg), reprinted as chapter 4 in Cook, The Logical and Legal Bases of the Conflict of Laws (I942).
} 
applies"; hence the children took no interest under the will, and the property passed to A's devisees. Richardson v. Roney. ${ }^{x}$

Centuries have elapsed since it has last been seriously contended that the word "heirs" designated an independent class of purchasers when used as part of the traditional fee simple conveyance "to A and his heirs." Actually, most American jurisdictions have by statute abrogated the rule of the common law requiring words of inheritance as a formal requisite to the conveyance of a fee simple. ${ }^{3}$ With understandable caution, however, conveyancers have hesitated to discard the traditional formula for conveying a fee simple.

Desiring to give effect to all the words in the instrument, and at the same time aware that the words "and his heirs" are surplusage if a fee be given A, conceivably, a court might be persuaded that it was the intention of the grantor or testator to give A something less than a fee, with "his heirs" being designated as a class of purchasers. This forecast may be speculative. Yet, the fact that the court, while it reached a proper result in the instant case, was nevertheless disturbed by a normal variant of "to A and his heirs" suggests that such a departure is not inconceivable. A court should have no trouble with a devise to "the brothers and sisters and their heirs" unless it is beginning to look for special significance in the phrase "and their heirs." 4

Whatever doubts the court may have had as to the nature of the limitation to the heirs of the brothers and sisters, it is perfectly clear that the rule in Shelley's Case had no application to the devise. The rule in Shelley's Case is a rule of law which applies to give A a fee only when there is an estate for life limited to A with a remainder to A's heirs. ${ }^{5}$ In applying the rule in this case, the court regarded itself as confronted with what it regarded as an earlier contrary decision in the case of Gehlbach $v$. Briegal. ${ }^{6}$ In that case, the provision of the deed was as follows: To $B$ and

$\times 382$ Ill. 528, 47 N.E. $2 \mathrm{~d} 7 \mathrm{I4}$ (1943).

2 Holdsworth, An Historical Introduction to the Land Law 53 (1927).

3 Mllinois first enacted a statute directed to this end in $\mathrm{x} 837$. Ill. L. $\mathrm{I}_{4}$ ( $(1837)$.

4 The fact that the correct result was achieved does not serve to justify the rationale. If at some future time the rule in Shelley's Case is abolished in Illinois, the court might on the precedent of this case acquiesce in an argument that some similar variant of "to $A$ and his heirs" was within the operation of the rule and consequently within the purview of the statute abolishing the rule. Under most statutes, this would result in A's taking a life estate with the remainder to his heirs as purchasers. Note 19 , infra.

5 This is a convenient simplification of the rule which does not cover all technical possibilities. The classic definition is that of Lord Coke. Shelley's Case, x Co. Rep. 93b, ro4a (r58r).

${ }^{6} 359$ Ill. 316, I94 N.E. 59I (1934). 
her husband, "for and during their lifetime, then to the heirs of the body of our daughter, [B], and if she leaves no child or children surviving her, then to her heirs according to law."7 Perhaps because the remainder was contingent both as to the person who was to take and also on the event of the daughter's leaving no surviving child, the court held in effect that the rule in Shelley's Case did not apply to contingent remainders. ${ }^{8}$

While the court in the instant case reconsidered and properly overruled its earlier decision in the Gehlbach case, the two cases are readily distinguishable. In the Gehlbach case, there was a limitation to a life tenant with a remainder contingent on certain events to the life tenant's heirs, a situation properly within the rule in Shelley's Case. In the instant case, whatever construction is given the word "heirs," it does not refer to the heirs of the life tenant; hence the devise is not subject to the application of the rule.

The instant case is representative of the general misunderstanding surrounding the application of the rule in Shelley's Case. That the rule has long survived its historical justification is generally conceded. Once regarded as a rule of construction, rigidity set in and the rule now admittedly operates in derogation of the manifest intent of testators and grantors. 9 Notwithstanding almost universal condemnation, an occasional defense will be interposed. In a recent article, ${ }^{\text {xo }}$ two writers suggest that the rule should be retained as giving effect to the rule of law favoring the vesting of estates. ${ }^{\text {II }}$ It would seem that whatever force this argument may have, it is far overshadowed by the desirability of permitting a property owner to dispose of his property in whatever manner he sees fit. The law has, of course, imposed certain restrictions upon freedom of disposition, such as the rule against perpetuities, the rule against accumulations, and the rule against restraints on alienation. If the rule in Shelley's Case is to constitute another such restriction, this should be expressed openly and not in an ambiguous and irrational manner. Thus, for ex-

7 Ibid., at 3 I 7 and 592 .

${ }^{8}$ This decision was clearly against the weight of authority and provoked much criticism. 3 Univ. Chi. L. Rev. I3I (I935); 45 Yale I. J. 352 (I935).

9 The Application of the Rule in Shelley's Case, to Univ. Chi. L. Rev. 344 (1943).

*o Green and Barth, The Rule in Shelley's Case, 3 I IIl. Bar J. 303 (I943).

II The particular article is subtitled, "Is It Wise to Substitute Contingent Remainders for Vested Titles?" The authors further urge that, since in their opinion a class of persons designated as "heirs" can take only by descent, the rule in Shelley's Case realizes the intention of the grantor or testator by giving the ancestor a descendible estate. They concede that the ancestor may convey or devise this property to persons other than his heirs-which concession, from any practical point of view, means that the rule operates to defeat, not to assist, the intention of the grantor or testator. 
ample, the rule does not extend to personal property $;^{; 2}$ in any case the rule may be readily avoided by careful draftsmanship. ${ }^{{ }^{3}}$ On the other hand, the rule against perpetuities is invariable and uniform in its application, ${ }^{\mathrm{I} 4}$ as are for the most part the other rules restraining alienation.

Another argument of somewhat the same vein is that the abrogation of the rule in Shelley's Case would cast land titles in doubt. This argument is answered by the uncertainty induced by the various decisions involving the application of the rule. Thus, in the instant case, the court felt compelled to reverse its earlier decision in the Gehlbach case. And in several other decisions ${ }^{15}$ the rule has been held to apply where the life estate to the ancestor has failed at the time when the instrument becomes operative. Although these decisions were not without some historical precedent ${ }^{16}$ one might surmise that they were something of a surprise to the legal profession. Furthermore, in more than one hundred decisions in Illinois the question of the application of the rule in Shelley's Case has been raised. ${ }^{17}$ In the majority of these cases, the question was one of construction to determine whether the technical language required by the rule was present. ${ }^{88}$ In many of these decisions, the devise or deed had been operative for many years.

It is submitted that there is little justification for the continued retention of the rule. A controversial decision of the Illinois Supreme Court in the case of Lydick $v$. Tate $e^{19}$ has resulted in a revival of discussion

12 This proposition seems to have been settled in Tllinois by Lord v. Comstock, 240 Ill. 492, 88 N.E. IOI2 (IgOg).

${ }_{3}$ For example, if the limitations are of different quality, that is, one legal and one equitable, the rule would not apply. Another device would be to have the second limitation take effect as an executory limitation. The result, of course, is that only the unwary are caught.

14 Gray, The Rule against Perpetuities $\$ \S 20 I-210$ (R. Gray ed. 1942).

${ }^{15}$ Lydick v. Tate, 380 IIl. 6r6, 44 N.E. 2d 583; Belleville Savings Bank v. Aneshaensel, 298 IIl. 292, I3I N.E. 682 (I92I).

${ }^{16}$ The Application of the Rule in Shelley's case, xo Univ. Chi. L. Rev. 344 (1943).

17 Carey and Schuyler, Illinois Law of Future Interests $\$ 93$ (I94I).

${ }_{18}$ The rule in Shelley's case, itself, is a rule of law. As a preliminary matter, however, it is necessary to determine whether by the ordinary rules of construction, the technical words are present. Leach, Cases and Materials on the Law of Future Interests I20-22 (2d ed. I940).

${ }^{29} 380 \mathrm{IIl} .616,44$ N.E. (2d) 683 (I942). In that case, certain property was devised to A for life or until she remarried, and upon her death or remarriage, to her heirs. At the time of the execution of the will, A was unmarried, but she later married during the life of the testator and was married at the time of his death. The court held that A took an estate in fee simple by virtue of the rule in Shelley's Case. This decision has been the subject of considerable discussion: Klockau, Lydick versus Tate, 3r IIl. Bar J. 236 (1943); Green and Barth, op. cit. supra, note Io; The Application of the Rule in Shelley's Case, Io Univ. Chi. L. Rev. 344 (1943); 43 Col. L.Rev. 398 (I943); 3 I Ill. Bar J. 324 (I943); 32 Ill. Bar J. 9 I (I943). 
among the members of the legal profession concerning the desirability of the rule. Probably as a consequence of this current interest, the Illinois State Bar Association is presently proposing certain legislation with the end of abolishing the rule. ${ }^{20}$ Certainly, the Illinois legislature would perform a valuable service by removing from the law of property this source of uncertainty which has resulted in such voluminous litigation. Legislatures in most other jurisdictions have long been enthusiastically attacking the rule; but they frequently fail to achieve complete success. A combination of poor statutory draftsmanship in failing to cover all possible applications of the rule, coupled with the fact that such a statute would be in derogation of the common law and hence would be construed strictly, have been the principal pitfalls. ${ }^{25}$ However, this difficulty is largely technical and could be surmounted by a carefully drafted statute. ${ }^{22}$

${ }^{20}$ The writer has been informed that this proposed legislation will be discussed at length in a forthcoming issue of the Illinois Law Review by Mr. Elmer M. Leesman, a member of the sponsoring committee of the Tllinois State Bar Association. In addition to the section providing for the abrogation of the rule in Shelley's Case, other sections will deal with other problems in the law of present and future interests in realty and personalty in Illinois. The proposed act is modelled in part after The Uniform Property Act as adopted by the National Conference of Commissioners on Uniform State laws. The Uniform Property Act, 9 U.L.A. $6 \mathrm{r}_{3}\left(\mathrm{r}_{942}\right)$.

${ }^{2 x}$ Simes, The Law of Future Interests $\$ \S x_{35}-142$ (1936).

${ }^{22}$ Another type statute worthy of consideration is the following elaborate West Virginia statute: "Wherever any person, by conveyance inter vivos or by will, takes an estate of freehold in land, or takes such an estate in personal property as would be an estate of freehold, if it were an estate in land, and in the same conveyance or will an estate is afterward limited by way of remainder, either mediately or immediately to his heirs, or the heirs of his body, or his issue, the words "heirs," "heirs of the body," or "issue" or other words of like import used in the conveyance or will, in the limitation therein by way of remainder, shall not be construed as words of limitation carrying to such person the inheritance as to the land, or the absolute estate as to the personal property, but they shall be construed as words of purchase, creating a remainder in the heirs, heirs of the body, or issue; it being the intent and purpose of this section to completely abolish the rule of law known as the Rule in Shelley's Case." W. Va. Code Ann. (Michie, 1937) $\$ 3534$. A simple, and perhaps a safer, expedient, in that the possibility of overlooking one of the exceptional ramifications of the rule is obviated, is that adopted by Kansas in simply abolishing the rule in Shelley's Case as such without attempting to define its scope. Kan. Gen. Stat. (Supp., I939) $\$ \$ 58-502,5^{8-503}$. 